\title{
Discourse Analysis of a Song Lyric Entitled "We Will Not Go Down"
}

\author{
Faizal Risdianto \\ IAIN Salatiga \\ faizrisd@gmail.com
}

\begin{abstract}
This library research aimed at finding the three aspect of discourse analysis: contextual, grammatical and lexical aspect of Michael Heart's song lyrics entitled "We will not go down (Song for Gaza). After analysis it can be found that the life experience and background of the song writer and singer is closely related to the idea proposes within the song lyrics. Whereas, the result of the grammatical and lexical analysis gives a depiction of cohesion and coherence of the song discourse of "We will not Go Down (Song for Gaza)". There are eight (8) forms of first plural personal pronoun of "We", four (4) second plural personal pronoun of "You" and seven (7) third personal pronouns in various forms. On the other side, it is difficult to find lexical aspects of this song discourse. There is only one form of anaphoric repetition. The repetition of the sentence "We Will Not Go Down" seven times is to influence the hearers whether they are supporters or opponents of the idea brought by the singer/the author that whatever happens Palestinian people will not surrender to every force, nation or people that want to colonialize them.
\end{abstract}

Key words: Discourse analysis, Song for Gaza, Palestinian people.

\section{Abstrak}

Riset pustaka ini bertujuan untuk menemukan tiga aspek analisis wacana: kontekstual, gramatikal dan leksikal dalam lirik lagu berjudul "We will not go Down (Song for Gaza)" karya Michael Heart. Setelah 
diadakan analisis dapat diketahui bahwa pengalaman dan latar belakang kehidupan seorang penulis and penyanyi lagu sangat berkaitan dengan ide yang dikemukakan dalam lirik lagu tersebut. Sedangkan hasil analisis gramatikal dan leksikal memberi gambaran adanya kohesi dan koherensi dalam lirik lagu. Terdapat delapan (8) bentuk pronomina pertama jamak, empat (4) pronominal kedua jamak dan tujuh (7) pronominal ketiga dalam bentuk yang bervariasi. Di sisi yang lain, sulit menemukan aspek leksikal dalam wacana lagu. Hanya ada satu bentuk repetisi anaforis. Pengulangan tujuh kali kalimat "We will not go down" dimaksudkan untuk mempengaruhi pendengar entah mereka mendukung atau menentang ide yang dikemukakan penulis atau penyanyi lagu bahwa apapun yang terjadi orang Palestina tidak akan menyerah kepada kekuatan, bangsa atau orang yang ingin menjajah mereka.

Kata kunci: Analisis Wacana, Lagu untuk Gaza, Orang Palestina.

\section{Introduction}

Human is social living being, who always need company in their life. It is hard to imagine that they should live alone without anyone to accompany them. They always need others in order to facilitate their efforts to provide themselves with their necessities of life. To carry out the cooperation among others, they need a means of communication, which is called 'language'.

Hornby (1992:62) defines that language is a system of sounds and words used by humans to express their thoughts and feelings. Other definition is given by Carrol as quoted by Ramelan that language is an arbitrary system of sounds or sequences of speech sounds which is used or can be used to interpersonal communication (Ramelan, 1992:10). In other words, it can be said that language is a system of sounds used as a means to communicate human's feelings 
and thoughts with others. Ramelan states that the use of language enables the members of a social group to cooperate with one another for their own benefits .Regarding the use of language, the writer can say that the role of language is very important in human life as a means to communicate ideas, feelings and desires among individuals as the part of social community. By the use of language, we can communicate and express our ideas, our feeling and also share information with other people. One way to communicate with language is by the use of music.

The word "music" was derived from Greek word "mousike" taken from the name of God which led the world of art and science. The primary subject matters of music are feelings and sounds. These imply that the content of music is a revelation of feelings and sounds and that music gives us more sensitive understanding of them. According to Webster (1983:781) "music is the science of art ordering tones or sounds in succession, in combination and in temporal relationship to produce a composition having unity and continuity as well as rhythm, melody, and harmony as its elements". Greek philosophers and ancient Indian philosophers defined music as tones ordered horizontally as melodies and vertically as harmonies.

M. Stubbs' textbook (Stubbs 1983:1), discourse analysis is defined as:

a) concerned with language use beyond the boundaries of a sentence/utterance,

b) Concerned with the interrelationships between language and society and 
c) Concerned with the interactive or dialogic properties of everyday communication.

Discourse analysis is how texts relate to contexts of situation and context of culture, how texts are produced as a social practice, what texts tell us about happenings, what people think, believe etc., and how texts represent ideology (power struggle etc.) In this study, the writer will focus on the implication meanings of the Michael Heart's song lyric entitled "We will not Go Down (Song for Gaza)".

Michael Heart (born Annas Allaf ) is a Syrian American singer-songwriter, recording artist, guitarist, producer and audio engineer based in Los Angeles, CA. He was born in Syria and raised in Europe (Switzerland and Austria) and the United States. In January 2009, he composed and released a song in support of the Palestinian civilian victims of the Israeli war in Gaza. The song is called "We Will Not Go Down (Song for Gaza)" and gained popularity on sites like YouTube. The official YouTube video of the song was viewed over 1 million times within a month of its release; the recording of the song was broadcast on radio and television in many countries along with blogs and websites worldwide and it was chanted in many demonstrations in cities ranging from Sydney, Australia to London, England. The Palestine Argentine Delegation Embassy website also put the song with lyrics on its page.

Heart initially made the mp3 of the song freely downloadable from his official website, which he reports has been downloaded over 500,000 times, encouraging the listeners to make a donation to United Nations Relief and Works Agency for Palestine Refugees in the Near 
East (UNRWA). After incessant emails from people asking why the song hadn't been made available on iTunes, he finally uploaded it to the Apple music site in July 2010.

There are many people who like to listen to this song, but they don't really know the true meaning of this song, especially in Indonesia. So the writer specifies the problem through the following question: What are the contextual, grammatical and lexical aspect of the song lyrics entitled "We Will not Go Down" by Michael Heart?. It is hoped that after reading this paper, the readers can be able to know the true meaning of this song, so they not just able to sing it and listen to it, but they can also understand it.

\section{Research Methodology}

In conducting this study, the writer used the qualitative approach which means that the data were analyzed qualitatively. Berg (1989:2) states that "quality refers to the what, how, when, and where of a thing-its essence and ambience. Qualitative research thus refers to the meanings, concepts, definitions, characteristics, metaphors, symbols, and description of things." The data in this study is in the form of paraphrasing the song lyrics of We Will not Go Down by Michael Heart. There are two kinds of data in this research: main or primary data and secondary data.

The main data was taken from Michael Heart's song entitled "We Will not Go Down (Song for Gaza)". The secondary data were taken from the relevant sources from the internet that may support the analysis and find the answer from the problems. 
The procedure of collecting the data in this study was divided into several steps: (1) Reading - In the first step, the writer will read and re-read and also listen to the song in order to get the meaning and the feeling. (2) Analyzing - Next is analyzing the words which need to be explained to find the meaning. (3) Reporting - The data which had been analyzed will be drawn in the form of conclusion by paraphrasing the song based on the implicated meaning.

The theme of the song is about the struggle of the Moslems against the Zionist Israel's army. People of Palestine still do not want to give up even though Israel has destroyed homes, schools and mosques of the Moslems. The Israel's army has killed so many people of Palestine. So many women and children killed in the war. However, the Muslims still want to fight with Israel's army.

\section{Discussion \& Finding}

Text might be said that the term of the text is restricted to written language. Modern linguistics has introduced the concept of text that includes every type of utterance. For examples, text may be a magazine article, a television interview, a conversation or a cooking recipe. Besides that, according to De Beaugrande and Dressler (1981), text is defined as communicative events which have seven criteria; there are: cohesion, coherence, intentionality, acceptability, informative, situational, and textual.

The term of discourse is restricted to spoken language. Discourse is influenced by contexts of situation and context of culture, how texts are produced as a social practice, what texts tell us about 
happenings, what people think, believe etc., and how texts represent ideology (power struggle etc.). Discourse competence refers to the selection, sequencing, and arrangement of words, structures, and utterances to achieve a unified in spoken. This is where the top-down communicative intent and socio-cultural knowledge intersect with the lexical and grammatical resources to express message and attitudes and to create coherent texts.

Lyrics (in singular form Lyric) are a set of words that make up a song. The writer of lyrics is a lyricist or lyrist. The meaning of lyrics can either be explicit or implicit. Some lyrics are abstract, almost unintelligible, and, in such cases, their explication emphasizes form, articulation, meter, and symmetry of expression. The lyricist of traditional musical forms such as Opera is known as a librettist.

Lyric derives from the Greek word lyrikos, meaning "singing to the lyre". The word lyric came to be used for the "words of a song"; this meaning was recorded in 1876. The common plural (perhaps because of the association between the plurals lyrics and words), predominates contemporary usage. Use of the singular form lyric remains grammatically acceptable, yet remains considered erroneous in referring to a singular song word as a lyric.

Lyrics can be studied from an academic perspective. For example, some lyrics can be considered a form of social commentary. Lyrics often contain political, social and economic themes as well as aesthetic elements, and so can connote messages which are culturally 
significant. These messages can either be explicit or implied through metaphor or symbolism.

\section{Contextual and Inferential Analysis}

There are several contexts within this analysis that is sociocultural and situational contexts. Based on this contextual analysis then it will be explained about inferential aspect.

\section{Socio-Cultural contexts}

The comprehension of cultural and social context can be developed through the understanding of external context analysis of a discourse (Sumarlam, 2003:5). In this case, it can be observed the cultural and social context by trying to find out the background of the making of the song lyrics. Reading articles from websites and blogs it can be known that during the war in Gaza, Michael Heart wrote a humanitarian song entitled "We will not Go Gown (Song for Gaza)" in January 2009. It is written in order to support of the Palestinians victims from the Israeli Aggression.

The song was very well-known in all over the world because it is spread as a free MP3 which means it can be downloaded without any charge. It has been downloaded by over half a million people from the official websites and not yet counted from other web-sites. More than 500 new clips have been made with "We Will Not Go Down" by people all over the world, and thousands of websites have uploaded the clip and posted the lyrics. As the first release, the official video on YouTube has viewed by over one million people within the 
first month. And the appreciations of the song are very high since the statistic shows that over 10,000 e-mails, comments, and messages are sent to respond this song. The protest towards Palestinians victims can be seen from these lines of song lyrics:

(1) A blinding flash of white light

(2) Lit up the sky over Gaza tonight

(3) People running for cover

(4) Not knowing whether they're dead or alive

(5) They came with their tanks and their planes

(6) With ravaging fiery flames

(7) And nothing remains

(8) Just a voice rising up in the smoky haze

(9) We will not go down

(10) In the night, without a fight

(11) You can burn up our mosques and our homes and our schools

(12) But our spirit will never die

(13) We will not go down

(14) In Gaza tonight

(15) Women and children alike

(16) Murdered and massacred night after night

(17) While the so-called leaders of countries afar

(18) Debated on whose wrong or right

(19) But their powerless words were in vain 
Discourse Analysis of a Song Lyric Entitled "We Will Not Go Down"

(20) And the bombs fell down like acid rain

(21) But through the tears and the blood and the pain

(22) You can still hear that voice through the smoky haze

(23) We will not go down

(24) In the night, without a fight

(25) You can burn up our mosques and our homes and our schools

(26) But our spirit will never die

(27) We will not go down

(28) In Gaza tonight

(29) We will not go down

(30) In the night, without a fight

(31) You can burn up our mosques and our homes and our schools

(32) But our spirit will never die

(33) We will not go down

(34) In the night, without a fight

(35) We will not go down

(36) In Gaza tonight

In addition, the song has also been translated into a dozen languages and subtitled on numerous clips. Besides his popularity achieved from the song, he also received some critiques. The first, of course, comes from the Israeli politician because they would get the disadvantages from it. Besides that, many people also claimed that Heart is a follower of any particular religion. Therefore, to encounter that, Heart explained that the song has nothing to do with religion. It is 
only a humanitarian song in nature. Based on the above explanation, it can be drawn to the conclusion that how phenomenal this song so it can gain many respects, responds, or claims from many people around the world.

\section{Situational Context}

Situational context consists of physical, epistemic, social context with personal, locational and temporal analogical interpretation principle:

a. Physical context. These are some aspects of physical context and its analysis.

(1) Based on locational interpretation, the real situation which is expressed in this song lyric is in chaotic area of Gaza, Palestine and the far away countries neglecting the suffering of Palestinian people.

(2) The topic of conversation is the voice and steadfastness of Palestinian people facing the dreadful terror of Israeli murdered and massacred Palestinian people for years.

b. Epistemic Context

Based on epistemic context, it can be assumed that there is a common understanding between the speaker/the writer of song lyrics and the hearer/the reader about the bittering truth and evidence of the misery of Palestinian people particularly in the area of Gaza and the importance of establishing world's peace. 


\section{c. Social context}

In the perspective of participant's activeness, this discourse can be categorized as a monologue discourse (Baryadi, 2002:10). This discourse does not involve the hearer who can turn as the hearer treats in this discourse remains to be the hearer.

The interpretation about the hearer in social context can be viewed by analyzing the speeches of the speaker. The misery or the suffering of Palestinian Gaza is the saddening problem that worries the speaker so much. It is a naked truth that the more powerful terrorizing, murdering and destroying the weak without any accepted rational and humanistic consideration for normal healthy-minded people. In Social life this is a shameful thing and a dreadful violation of human rights.

\section{Grammatical Aspect analysis}

Grammatical aspect analysis in discourse analysis consists of reference, substitution, elliptical aspect, and conjunction. These are some grammatical aspect found in the analysis of song lyrics of "We will not Go Down (Song for Gaza)".
1. Reference
a. Personal Reference 
First personal reference found in song lyrics of "We will not Go Down (Song for Gaza) can be viewed in line of these verses below:

(9) We will not go down

(13) We will not go down

(23) We will not go down

(27) We will not go down

(29) We will not go down

(33) We will not go down

(35) We will not go down

The element of "We" in line (9), (13), (23), (27), (29), (33) and (35) is the first plural personal pronoun reference. In this case, the element of "We" refers to the voice of Palestinian Gaza and for everyone who support the struggle of Palestinian people to achieve their independence from the annexation of Israel.

The second personal reference in this song can be seen in line of these verses:

(11) You can burn up our mosques and our homes and our schools

(22) You can still hear that voice through the smoky haze

(25) You can burn up our mosques and our homes and our schools

(31) You can burn up our mosques and our homes and our schools 
All the elements of "You" in line (11), (22), (25) and (31) refer to the hearer. The use of the word "You" here refer to plural personal pronoun reference.

The third personal reference in this song can be seen in line of these verses:

(1) A blinding flash of white light

(3) People running for cover

(5) They came with their tanks and their planes

(8) Just a voice rising up in the smoky haze

(15) Women and children alike

(17) While the so-called leaders of countries afar

(19) But their powerless words were in vain

(20) And the bombs fell down like acid rain

All the elements of "A blinding flash of white light" in line (1), "People" in line (3), "They" in line (5), "A voice" in line (8), "Women and children" in line (15), "Leaders of countries afar" in line (17), "Powerless words" in line (19) and "the bombs" in line (20) refer to the third personal pronoun reference. All of them consist of two category: the plural third personal pronoun like "People", "They", "Women and children", "leaders of countries afar", "powerless words" and "the bombs" and there are only two data of singular third personal pronoun found in the song lyrics "A blinding flash of white light" in line (1) and "A voice" in line (8). 
b. Demonstrative reference

Demonstrative reference is easily marked by the use of the forms of "this", "that", "these", and "those" and there is only one data can be found in the song lyrics:

(22) You can still hear that voice through the smoky haze

The use of "that" on the phrase "that voice" refers to the voice of freedom in the mind of Palestinian People.

\section{Substitution}

Substitution is the replacement of particular element which refers to the same realities (Sumarlam, 2003: 28).

This substitution can be seen in the line of verses below:

(3) People running for cover

(4) Not knowing whether they're dead or alive

(8) Just a voice rising up in the smoky haze

(19) But their powerless words were in vain

The word "They" in line (4), "a voice" in line (8), "their" in line (19) refer to Palestinian people that is simply wrote by the song writer as "people" in line (3).

\section{Elliptical aspect}

Elliptical grammatical aspect can be viewed below: 
Discourse Analysis of a Song Lyric Entitled "We Will Not Go Down"

(3) People Ørunning for cover

(4) Not knowing whether theyØ're dead or alive

(8) Just a voice Ørising up in the smoky haze

(21) But through the tears and the blood and the painØ.

(22) You can still hear that voiceØ through the smoky haze

The actual grammatical construction is:

(3) People (of Palestine are) running for cover

(4) Not knowing whether they (are) dead or alive

(8) Just a voice (which is) rising up in the smoky haze

(21) But through the tears and the blood and the pain (of Palestinian)

(22) You can still hear that voice (of Palestinian) through the smoky haze

\section{Conjunction}

There are some elements of conjunction which can be found in the song lyrics "We will not Go Down (Song for Gaza)":

(4) Not knowing whether they're dead or alive

(5) They came with their tanks and their planes

(7) And nothing remains

(11) You can burn up our mosques and our homes and our schools

(15) Women and children alike

(16) Murdered and massacred night after night

(19) But their powerless words were in vain

(20) And the bombs fell down like acid rain 
(21) But through the tears and the blood and the pain

(25) You can burn up our mosques and our homes and our schools

(26) But our spirit will never die

(31) You can burn up our mosques and our homes and our schools

(32) But our spirit will never die

There are 11 forms of conjunction "And" in line (5), (7), (11), (15), (16), (20), (21), (25) and (31) whereas there are four (4) forms of conjunction "but" in line (19), (21), (26) and (32). There is only one data of the form of conjunction "or" in line (4).

\section{Lexical Aspect Analysis}

Lexical aspect used in this discourse to support cohesion and coherence in semantic perspective. There are some lexical aspects in the song lyrics "We will not Go Down (Song for Gaza)".

\section{Repetition}

The terminology used in this repetition refers to the terminology used by Gorys Keraf (in Sumarlam, 2003:35). In this discourse there is only one form of repetition that is anaphoric repetition. Anaphoric repetition is the repetition of lingual constituent in a form of word or the initial phrase on every verse or subsequent sentence. The sentence " $\underline{\boldsymbol{W e}}$ will not go down in line (9) is repeated in the sentence in line (13). And it is also repeated without change in line (13), (23), (27), (29), (33) and (35). 
(9) We will not go down

(13) We will not go down

(23) We will not go down

(27) We will not go down

(29) We will not go down

(33) We will not go down

(35) We will not go down

The objective of the repetition of the sentence "We will not go down" seven times is to influence the hearers whether they are supporters or opponents of the idea brought by the singer/the author that whatever happens Palestinian people will not surrender to every force, nation or people that want to destroy and take the legacy of their ancestors. The Israeli may burn up Palestinian mosques, homes and schools but they cannot destroy their zeal or enthusiasm to fight against the enemies or colonialists.

\section{Synonymy}

Synonymy can be found in these verses:

\section{(1) A blinding flash of white light}

(20) And the bombs fell down like acid rain

In the first line of the song lyrics there is a phrase "a blinding flash of white light" which has a synonymic relation to the phrase "the bombs" in $20^{\text {th }}$ line.

\section{Conclusion}


The song lyrics "We will not Go Down (Song for Gaza) has been analyzed based on the aspects of discourse analysis. Contextual aspect illustrates a vivid picture of song lyric reality and song writer's reality. Many efforts had been made to comprehend contextual aspects. One of them is investigating the background and the life experience of the song lyric author and singer and then it is connected to the speeches of the verses or lines produced in the song lyrics. Music news from internet gives great contribution to the understanding of the contextual meaning and analysis.

The result of the grammatical and lexical aspect gives a depiction of cohesion and coherence of the song discourse of "We will not Go Down (Song for Gaza)". It can be seen that there are eight (8) forms of first plural personal pronoun of "We", four (4) second plural personal pronoun of "You" and seven (7) third personal pronoun in various forms like the elements of "A blinding flash of white light", "People”, “They”, ,A voice”,"Women and children”, "Leaders of countries afar", "Powerless words" and "the bombs".

On the other side, it is difficult to find lexical aspects of this song discourse. There is only one form of anaphoric repetition. It is the repetition of the sentence "We Will Not Go Down" seven times is to influence the hearers whether they are supporters or opponents of the idea brought by the singer/the author that whatever happens Palestinian people will not surrender to every force, nation or people that want to destroy and take the legacy of their ancestors.

\section{References}


Alba-Juez, Laura. 2009. Perspectives on Discourse Analysis: Theory and Practice. England: Cambridge Scholars Publishing.

Baryadi, 2002. Dasar-Dasar Analisis Wacana dalam Ilmu Bahasa. Yogyakarta. Pustaka Gondosuli.

BeauGrande, Robert \& Ulrich, Dressler. 1981. Introduction to text Linguistics.London.Longman Press.

Berg, L. Bruce, (1989). Qualitative Research Methodes for the Social Science: Introduction to Qualitative Research. Methods. New York: John Wiley and Sons Press.

Halliday MAK, Hasan R (1976) Cohesion in English. Longman, London.

Hornby, A.S. Oxford Advanced Learner's Dictionary of Current English. England. Oxford University Press.

Ramlan, 1992. Introduction to Linguistic analysis.Semarang.IKIP Press.

Sumarlam. 2003. Teori dan Praktik Analisis Wacana. Surakarta. Pustaka Cakra.

Stubbs, Michael. 1983. Discourse Analysis..Chicago.University of Chicago Press.

Webster's Ninth New Collegiate Dictionary. Merriam-Webster Inc, 1983

Michael Heart 'We will not Go Down' played in London Gaza Rally 17th Jan 2009 YouTube video

"We will not go down (Song for Gaza)" Official Video at YouTube http://www.rabble.ca/rabbletv/program-guide/best-net/songgaza-we-will-not-go-down http://www.alertnet.org/db/blogs/29542/c1be2c8229a2af970d6 f1f2767c8646c.htm http://www.groundreport.com/Arts_and_Culture/WE-WILLNOT-GO-DOWN-Song-for-Gaza/2888268 http://www.michaelheart.com/Michael_Heart Bio.html http://www.palestina.int.ar/noticias/Enero08/Noticia 452.html http://www.michaelheart.com/Song_for_Gaza.html https://en.wikipedia.org/wiki/Michael_Heart 